\title{
Evaluation of cellular and antioxidant effects of casein hydrolysates
}

\author{
N. Lahart ${ }^{1}$, S. A. Aherne ${ }^{1}$, D. O’Sullivan ${ }^{2}$, R. J. FitzGerald ${ }^{2}$ and N. M. O'Brien ${ }^{1}$ \\ ${ }^{1}$ School of Food and Nutritional Sciences, University College Cork, Republic of Ireland and ${ }^{2}$ Department of Life Sciences, \\ University of Limerick, Republic of Ireland
}

Casein hydrolysates can influence numerous processes within the body, including gastrointestinal, immunological, neurological and nutritional responses ${ }^{(1)}$. Previously, we assessed eight different casein hydrolysates for potential bioactivity and found that these samples exerted varying effects on human Jurkat $\mathrm{T}$ cell viability, proliferation, antioxidant activity and cytokine production ${ }^{(2)}$. Consequently, the casein hydrolysate that exerted the most bioactive effects was further hydrolysed to varying degrees and the subsequent hydrolysates were labelled B-E. Intact sodium caseinate was included as an unhydrolysed control (A). The aim of the present study was to assess if the bioactive effects of casein hydrolysates $\mathrm{A}-\mathrm{E}$ were dependent on the extent (or degree) of hydrolysis.

Jurkat $\mathrm{T}$ cells were supplemented with $0.5 \%(\mathrm{v} / \mathrm{v})$ casein hydrolysates B-E and intact sodium caseinate (A) for $24 \mathrm{~h}$ at $37^{\circ} \mathrm{C}$. Cell viability was determined using the MTT assay (Roche Diagnostics, West Sussex, UK). Membrane integrity was assessed using the lactate dehydrogenase (LDH, EC 1.1.1.27) release assay. Cellular glutathione (GSH) content was measured by the method of Hissin and Hilf ${ }^{(3)}$ and data were expressed as the percentage of untreated (control) cells.

\begin{tabular}{|c|c|c|c|c|c|c|c|}
\hline & \multirow{2}{*}{$\begin{array}{l}\text { Degree of } \\
\text { hydrolysis }\end{array}$} & \multicolumn{2}{|c|}{$\begin{array}{c}\text { Cell viability } \\
(\%)\end{array}$} & \multicolumn{2}{|c|}{$\begin{array}{l}\text { Membrane integrity } \\
\text { (\% LDH release) }\end{array}$} & \multicolumn{2}{|c|}{$\begin{array}{l}\text { GSH content } \\
(\% \text { control })\end{array}$} \\
\hline & & Mean & $\overline{\mathrm{SE}}$ & Mean & $\overline{\mathrm{SE}}$ & Mean & $\overline{\mathrm{SE}}$ \\
\hline Control & & 100.0 & 9.9 & 5.7 & 1.6 & 100.0 & 6.2 \\
\hline \multicolumn{8}{|l|}{$\mathrm{CH}:$} \\
\hline A & 0.00 & 109.4 & 4.4 & 2.8 & 1.4 & $37.8^{*}$ & 5.7 \\
\hline B & 0.70 & 86.8 & 17.4 & 3.3 & 1.0 & $142.6^{*}$ & 13.9 \\
\hline $\mathrm{C}$ & 1.33 & 114.8 & 11.8 & 2.0 & 1.0 & $136.6^{*}$ & 9.8 \\
\hline D & 3.41 & 89.8 & 10.8 & 2.1 & 0.9 & $139.2 *$ & 13.9 \\
\hline E & 10.80 & $71.9 *$ & 5.4 & 2.4 & 1.5 & 121.6 & 3.4 \\
\hline $\mathrm{F}$ & 19.88 & 105.6 & 5.8 & 2.7 & 0.4 & $134.1 *$ & 11.6 \\
\hline
\end{tabular}

$\mathrm{CH}$ : casein hydrolysate.

Values are means for four independent experiments. *Significantly different from control (untreated) cells: ANOVA, followed by Dunnett's test; $P<0.05$.

Casein (A) and its hydrolysates B, C, D and F did not affect cell viability as determined by the MTT assay, which measures mitochondrial activity. Treatment with sample E for $24 \mathrm{~h}$ significantly $(P<0.05)$ reduced the viability of Jurkat $\mathrm{T}$ cells. In terms of membrane integrity (LDH release), none of the casein hydrolysates induced adverse effects. When compared with control cells, samples B, C, D and F significantly increased $(P<0.05)$ cellular GSH content. On the other hand, the presence of intact sodium caseinate $($ A) significantly reduced the GSH content of Jurkat cells. In conclusion, there is no relationship between the degree of hydrolysis of this casein hydrolysate and its bioactive effects on human Jurkat $\mathrm{T}$ cells.

This work was supported by the Food Institutional Research Measure (FIRM) as administered by the National Development Plan $2006-2011$.

1. Phelan M, Aherne SA, FitzGerald RJ et al. (2009) Int Dairy J 19, 643-654.

2. Phelan M, Aherne SA, O'Sullivan D et al. (2009) Int Dairy J 19, 279-285.

3. Hissin PJ \& Hilf R (1976) Anal Biochem 74, 214-226. 